\title{
Late Pleistocene to Early Holocene Plant Movements in Southern Kyushu, Japan
}

\author{
Ayako Shibutani, Department of Comparative Studies, The Graduate \\ University for Advanced Studies, The National Museum of Ethnology, \\ 10-1 Senri Expo Park, Suita, Osaka 565-8511, Japan \\ E-mail: shibuchan0704@hotmail.com
}

\begin{abstract}
From the late Pleistocene to early Holocene in Japan, subtropical and temperate forest elements moved northwards. This affected human choices and access to food sources. More settled patterns of living spread northwards gradually, and northern hunting-gathering-fishing people began cultivating vegetables and cereal crops. This poster reports the presence of ancient starch residues on stone artefacts in Kagoshima Prefecture, southern Kyushu. The oldest residues recovered are dated by context to about $30,000{ }^{14} \mathrm{C}$ yr BP. If such residues can be identified, it may be possible to detect a hypothesized early phase of tropical plant movement northwards during warmer climate peaks in the late terminal Pleistocene, as well as during the long period of Holocene warming that followed. As an initial step towards identification, the morphological characteristics and condition of the starch granules are described and compared to those of other sites in early Japan.
\end{abstract}

Résumé: Au Japon, de la fin du Pléistocène au début du Holocène les forêts subtropicales et tempérées se sont déplacées vers le nord. Cela a affecté les choix et l'accès à l'alimentation des peuplades. La plupart se sont déplacées peu à peu vers le nord et après s'être consacrées à la chasse, la cueillette et la pêche, commencèrent à cultiver des légumes et des céréales. Ce poster montre la présence d'anciens résidus d'amidon sur des artefacts en pierre à Kagoshima, dans le sud de Kyushu. Les résidus les plus anciens ont été datés au carbone 14 à environ 30000 ans avant notre ère. Si de tels résidus peuvent identifiés, il peut être possible de détecter une hypothétique première phase du mouvement des plantes tropicales vers le nord durant les périodes les plus chaudes à la fin du Pléistocène, ainsi que durant la longue période de l'Holocène qui suivit. En tant que première étape de l'identification, la caractéristique et la condition des 
granules d'amidon sont décrites et comparées à ceux d'autres sites du Japon ancestral.

Resumen: Desde finales del Pleistoceno a principios del Holoceno, el bosque subtropical y templado de Japón se desplazó hacia el norte, circunstancia que afectó a la vida humana y su acceso a las fuentes de alimento. Los patrones de vida más sedentarios se fueron trasladando hacia el norte poco a poco y los pueblos cazadores-recolectores-pescadores del norte comenzaron a cultivar vegetales y cereales. Este cartel indica la presencia de antiguos residuos de almidón sobre instrumentos de piedra en la Prefectura de Kagoshima, al sur de Kyushu. Los vestigios más antiguos recuperados se han fechado por el contexto en torno al 30.000, 14 años de radiocarbono antes del presente. Si pueden identificarse estos vestigios, es posible que se detecte una fase temprana de movimiento de plantas tropicales hacia el norte, durante los picos climáticos más cálidos de la última fase del Pleistoceno, y también durante el largo calentamiento del Holoceno siguiente. Como paso inicial para la identificación, se están describiendo y comparando las características morfológicas y el estado de los glánulos de almidón con los de otros yacimientos del Japón prehistórico.

\section{KEYWORDS}

Grinding stones, Plant utilization, Starch residues, Japan, Southern Kyushu

\section{Introduction}

Japanese vegetation is floristically rich due to the diversity of climatic conditions and geographical features, and more than 5,000 species of higher plants have been identified. The distribution of Japanese vegetation is controlled in part by the East Asian monsoon. From south to north in the Japanese Archipelago, at present, there is a clear-shift from evergreen broad-leaved forest to deciduous broad-leaved and evergreen coniferous forests (summergreen broad-leaf zone) (Miyawaki 1977).

Japan has experienced major alternations in forest distribution through previous glacial and interglacial climatic cycles. Between 21,000 and 18,000 ${ }^{14} \mathrm{C}$ yrs BP (the Last Glacial Maximum), Japan was almost entirely covered with coniferous forest and cool-temperate forest (Tsukada 1983; Yasuda 1980). Around $18,000{ }^{14} \mathrm{C}$ yr BP, vegetation changed from boreal conifer forest to deciduous and evergreen broadleaf forest (Habu 2004; Yasuda 1980). Between 15,000 and 6,000 ${ }^{14} \mathrm{C}$ yrs $\mathrm{BP}$, the climate became warmer and more strongly monsoonal. This period is interpreted as a transitional stage from the Late Glacial climate to the climatic optimum in the middle Holocene. 
Subtropical and cool-temperate forest elements moved northwards (Fuji 2007; Okamura 1997; Yasuda 1980). These changes affected human access to wild food sources, and also presumably the viability of introduced cultigens from other regions.

The basis of food exploitation in early Japan was largely hunting and gathering. Broad spectrum exploitation of food sources from the sea, the rivers, and the mountains has been demonstrated (Matsui and Kanehara 2006; Suzuki 1988; Takahashi and Hosoya 2002). As temperate forests became more extensive, more settled patterns of living spread northwards gradually, and northern hunting-gathering-fishing people began cultivating vegetables and cereal crops.

In southern areas of Japan, climate warming and vegetation change were more rapid than in northern areas. People in the southern areas depended above all on plant sources. This is indicated by diverse archaeobotanical remains and the abundance of acorns and nuts in many sites. Preserving and processing techniques for plant foods were developed using earthenware and stone implements, and the changes in technology are associated with changes towards more settled life.

\section{Grinding Stones and Plant Utilization in Kyushu}

During the Last Glacial Maximum, Kyushu in southern part of Japan was mostly covered with cool-temperate forest. Stone tools and earthenware in this period were mainly used to process and store locally available wild food sources (Gotanda and Fukusawa 2006; Okamura 1997). Known wild plant sources were mainly chestnut (Castanea), horse-chestnut (Aesculus), beechnuts (Fagus), and various acorn species (Castanopsis, Lithocarpus, and Quercus). These remains with hard outer-shells have frequently been found in storage pits under waterlogged conditions. Large numbers of Quercus spp. cotyledons and shells have been recovered from many sites.

Between 17,000 and 7,000 ${ }^{14} \mathrm{C}$ yrs BP, temperate evergreen forests began to spread all over Kyushu (Gotanda and Fukusawa 2006; Pearson 2006). This vegetation change lead to shifts in plant-food exploitation from tannin-rich deciduous acorns to evergreen acorns following changes in oak distribution (Takahashi and Hosoya 2002; Watanabe 1975). Moreover, the ecological superiority of southern Kyushu under the evergreen forest brought forth the early mass production of pottery and the appearance of large scale settlements sooner than in other regions of Japan (Amemiya 1998; Obata 2004; Pearson 2006).

Stone implements, such as retouched and backed flakes, amorphous grinding stones, saddle-querns, and polished and chipped stone axes, have 
been found on many sites belonging to the early Holocene in southern Kyushu (Obata 2004). They were probably used for cutting grasses and wood, gathering roots, and grinding acorns and nuts.

Formed grinding stones appeared early in Kyushu, and then spread eastwards and northwards with the expansion of evergreen broad-leaf forest. After the evergreen broad-leaf forest reached as far as the Pacific coastline (at least $7,000{ }^{14} \mathrm{C}$ yr BP), these formed grinding stones ceased to be used in Kyushu. This was interpreted as a specific adaptation of plant sources by people to their environment (Kamijo 2007). This interpretation was based on the data provided by macrobotanical remains, pollen, and usewear analysis, before residue studies began in Japan.

This poster focuses on the morphological features and physical condition of residues of starchy tissues on early grinding stone tools in southern Kyushu. The aim is to learn about human diet during the early phase of plant movements northwards from the late terminal Pleistocene and early Holocene.

\section{Initial Results}

Fifteen stone artefacts found from four sites (Tachikiri, Kakuriyama, Soujiyama, and Okunonita sites) in Kagoshima Prefecture were examined to assess the preservation of starch residues. Kagoshima Prefecture is located at the southwest tip of Kyushu Island and has deep volcanic soils formed by a chain of active and dormant volcanoes.

The Tachikiri and Okunonita sites are located on Tanegashima, which is the second largest island in Kagoshima Prefecture. The occupation of the Tachikiri site was placed at about $30,000{ }^{14} \mathrm{C}$ yr BP (Tahira and Nohira 2003). Starch residues were found on two unformed grinding stones (sandstone) and two hand-stones (also sandstone). The Okunonita site was occupied at approximately $13,500{ }^{14} \mathrm{C}$ yr BP (Kodama and Nakamura 1995), and five unformed grinding stones (sandstone) and two hand-stones with small hollows (also sandstone) were examined. The Kakuriyama and Soujiyama sites are located in Kagoshima city. The former was continuously settled after about 12,000 yr BP (Tozaki et al. 1981), and starch granules were found on a single formed grinding stone (pyroxene andesite). The occupation of the Soujiyama site was placed at about 11,500 yr BP (Amemiya et al. 1992), and starch granules were found on one unformed grinding stone (sandstone) and two small hand-stones (also sandstone).

All samples were subject to minimal handling and protocols to avoid contamination are comparable to those used in most of ancient starch research (Loy and Barton 2006). Spot sampling (Fullagar 2006) was conducted on both working and non-working surfaces of stone tools to compare quantitative occurrence of starch residues. Gloves were not used while taking samples, but 
hands were washed before conducting each extraction from stones. Microscopy (System Microscope, Nikon ECLIPSE E600: 100-400× magnification) was employed to study starch under brightfield with cross-polarized light.

The total starch granule numbers recorded were 30 from the Tachikiri site, 18 from the Kakuriyama site, 156 from the Okunonita site and 8 from the

\section{Late Pleistocene to Early Holocene Plant Movements in Southern Kyushu, Japan \\ SHIBUTANI Ayako \\ Department of Comparative Studies", The Graduate University for Advanced Studies, Japan}

\section{Summary \\ Starch residues are abundant on early grinding stones found in southern Kyushu, Japan. As an initial step towards identification, the morphological characteristics and condition of the starch granules have been recorded}

\section{Background}

The districution of vegetation in Japan is controlled in part by the East Asian monsoon. From south to north, there is a forest to docidious brood-10aved ind evergreen conifercus forests (summergreen broad teat zono)
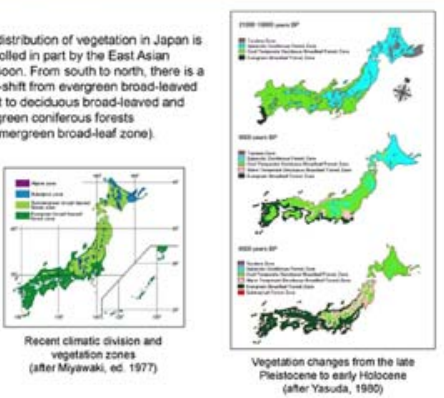

Betwoen 15,000-6,000 yours BP, the climate became wamer and mone stronoy monsoonal Suttropical and cool-temperate forest elements moved access to wild food sources, end aiko (presumably) the visberity of introduced culligens from ofter regions

2. Grinding stones and plant utilization in Kyushu

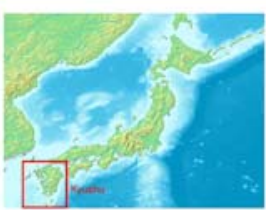

During the Last Glacial Maximum. Kyeshu was mostly covered with cool temperste tarest stone tod were mainly used lo process and stcre locally ava iloble wild food sources (Gotanda \& Fuluzzmia 2006: Okamura. 1997?

According to Kamio (2007), formed grinding stones appeared earier in Kyushu. and then spresc eastadds and northwses with the expans on d evergeen broad-led forest. This interpretabon was based on the data provided by macro. botanical remains, polten and usewear aralysis

Jomon period grinding stones in Kyushu

\begin{tabular}{|c|c|c|}
\hline & $\begin{array}{l}\text { Untomed } \\
\text { stones }\end{array}$ & $\begin{array}{l}\text { Formed } \\
\text { slones }\end{array}$ \\
\hline $12000-2000 \mathrm{EP}$ & 15 & 0 \\
\hline 000000000 & 100 & it \\
\hline $6000-5.000 \Leftrightarrow$ & $x$ & 0 \\
\hline $5000-4000$ ap & zo & 0 \\
\hline $4000-3,000 \mathrm{BP}$ & 224 & $2 \mathrm{~s}$ \\
\hline $3000-2.400 \mathrm{BP}$ & 42 & 0 \\
\hline
\end{tabular}

Known wid food sources include chestnut, horso-chestinut, beechnuts and various acom species (Costast

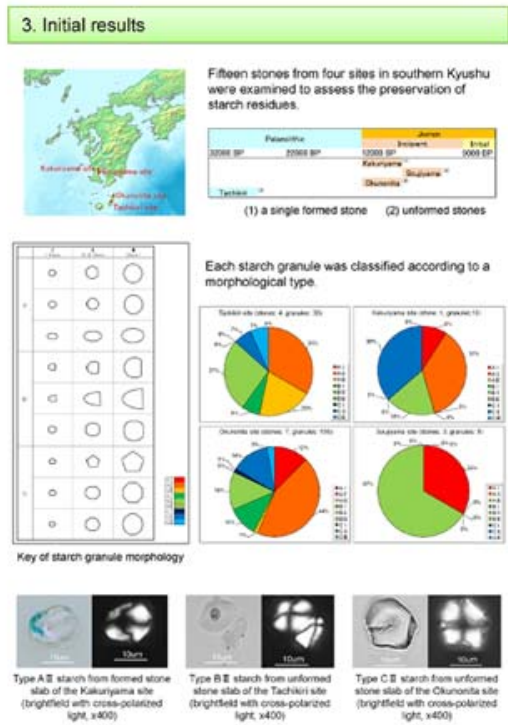

Conclusion

The morphological variation in ancient starch indicates that various plant species were available in southern Kyushu from the earliest period of known oceupation. To identify starch sources, comparisons must be made with wild and presumably indigenous food plants, and with other plants that may have been introduced as carly cultigens from tropical. subtropical, and temperate regions near Kyushu.

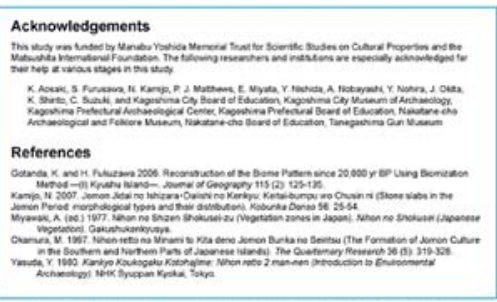

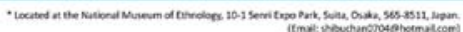


Soujiyama site. Starch preservation in these assemblages was variable. About $50 \%$ of starch granules were well preserved, with features that resemble those seen in fresh specimens (clearly defined outline and Maltese-cross, and with few or no fractures). The most common forms of degradation seen were pitting and breakage; the least frequent forms were disruption of the Maltese cross and only partial or poorly defined darkening with polarized light.

Each starch granule was classified according to morphological type based on a range of geometrical forms that correspond approximately to the range of variation seen in published images of starch and in our modern reference collection (the collection currently consists of 74 species and 49 genera from Japan). Type A is circular, and type B is semi-circular, triangular, or quadrangular. Type $\mathrm{C}$ represents polygonal (see a figure in an attached poster). Type A and type B forms sometimes appear within one reference sample, but type $\mathrm{C}$ forms have not been seen together with $\mathrm{A}$ and B. The size categories of I $(<10 \mu \mathrm{m})$, II $(10-20 \mu \mathrm{m})$, and III $(20 \mu \mathrm{m}<)$ refer to the maximum lengths of starch granules.

Basing the starch typology on geometrical form and size makes it possible to analyse morphological variations in the starch granule assemblage, and is a first step that can be taken before attempting the botanical identification of starch granules. The most common morphotype BII appeared on tools in all of four sites. The less common variants (AI, AII, and CII) were found on tools from three sites: type AI was found in the Kakuriyama, Okunonita, and Soujiyama sites; type AII was found in the Tachikiri, Kakuriyama, and Okunonita sites. Type CII was found in the Tachikiri, Kakuriyama, and Okunonita sites. The co-occurrence of type $\mathrm{C}$ with other forms of starch in these sites may indicate the presence of more than two plant species on the stone tools.

Although the Tachikiri and Okunonita sites were settled under similar environmental conditions (both in Tanegashima), there were remarkable differences in starch morphologies between these sites: the abundance of common variants (AII, BI, and CII), and the occurrence of morphotype AI and $\mathrm{CI}$ at the Okunonita site. These differences could signify changes in plant utilization between these sites, because southern Kyushu had already experienced the early phase of climatic warming and vegetation change when the Okunonita site was occupied at $13,500{ }^{14} \mathrm{C}$ yr BP.

\section{Conclusion}

The long-term preservation of crystalline and water-insoluble polymers in starch is not understood in terms of enzyme digestibility on multi-millennial scales. Despite the taphonomic challenges for starch preservation, preliminary starch analyses of archaeological stone artefacts have shown that starch can survive for long time periods without obvious protection from 
enzymatic attack (Atchison and Fullagar 1998; Fullagar 2006; Haslam 2005; Piperno and Holst 1998). There is often a greater abundance of starch on artefacts than in surrounding sediments and soils (Barton et al. 1998). Little is known about the taphonomic processes that may occur within the cavities and pores on stone tool surfaces. The existence of these residue traps does not immediately explain how starch escapes hydrolysis (Barton 2007; Mercader et al. 2008).

The present study shows that unmodified starch and modified or degraded starch granules may persist on stone tools as organic residues for at least 30,000 years. The morphological variation seen in ancient starch indicates that various plant species were available in southern Kyushu from the earliest period of known occupation in Japan. The co-occurrence of circular and polygonal starch granules on individual tools suggests that at least two plant species were utilized within the working life of individual grinding stones.

Taxonomic identification of these starch granules has not been attempted yet due to the paucity of comparative data and inherent difficulties posed by natural variability within starch sources. In order to identify the starch sources, comparisons must be made with wild and presumably indigenous food plants, and with other plants that may have been introduced as early cultigens from tropical, subtropical, and temperate regions near Kyushu.

\section{Acknowledgements}

This study was funded by Manabu Yoshida Memorial Trust for Scientific Studies on Cultural Properties and the Matsushita International Foundation. I thank P. J. Matthews for discussions of this paper and editorial assistance. The following researchers and institutions are also acknowledged for their help at various stages in this study. K. Aosaki, S. Furusawa, N. Kamijo, Y. Kudo, E. Miyata, Y. Nishida, A. Nobayashi, Y. Nohira, J. Okita, S. Seguchi, K. Shinto, S. Shoda, S. Sugiyama, C. Suzuki, N. Yamamoto, K. Yamazaki, Kagoshima City Board of Education, Kagoshima City Museum of Archaeology, Kagoshima Prefectural Archaeological Center, Kagoshima Prefectural Board of Education, Nakatane-cho Archaeological and Folklore Museum, Nakatane-cho Board of Education, Oumi Kaidzuka Kenkyukai (Ours), Tanegashima Gun Museum.

\section{Open Access}

This article is distributed under the terms of the Creative Commons Attribution Noncommercial License which permits any noncommercial use, distribution, and reproduction in any medium, provided the original author(s) and source are credited. 


\section{References Cited}

Amemiya, M.

1998. Minami Kyushu ni miru Jomon Teiju-syuryo-saisyumin Sekai [Huntinggathering people at the Jomon period in southern Kyushu]. Kikan Kokogaku (Quaternary Issue of Archaeology) 64:19-24.

Amemiya, M., M. Okamoto, H. Deguchi, and H. Naruo

1992. Soujiyama iseki [The Soujiyama Site]. Kagoshima-shi Maizo-bunkazai Hakkutsu Chosa Hokokusyo 12. Kagoshima-shi Kyoiku-iinkai, Kagoshima.

Atchison, J., and R. Fullagar

1998. Starch Residues on Pounding Implements from Jinmium Rock-Shelter. In A Closer Look: Recent Australian Studies of Stone Tools, edited by R. Fullagar, pp. 109-148. Sydney University Archaeological Methods Series, vol. 6. University of Sydney, Australia.

Barton, $\mathrm{H}$.

2007. Starch Residues on Museum Artefacts: Implications for Determining Tool Use. Journal of Archaeological Science 34:1752-1762. doi:10.1016/j.jas.2007. 01.007 .

Barton, H., R. Torrence, and R. Fullagar

1998. Clues to Stone Tool Function Re-examined: Comparing Starch Grain Frequencies on Used and Unused Obsidian Artefacts. Journals of Archaeological Science 25:1231-1238. doi:10.1006/jasc.1998.0300.

Fuji, N.

2007. Changes of the Natural Environment During the Jomon Period (Part 4): Change of the Paleovegetation. The Journal of Kanazawa Gakuin University: Business Administration, Economics, Informatics and Natural Sciences 5:139-164.

Fullagar, R.

2006. Starch on Artifacts. In Ancient Starch Research, edited by R. Torrence and H. Barton, pp. 177-203. Left Coast Press, Inc., Walnut Creek.

Gotanda, K., and H. Fukusawa

2006. Reconstruction of the Biome Pattern Since 20,000 yr BP Using Biomization Method - (I) Kyushu Island. Journal of Geography 115(2):125-135.

Habu, J.

2004. Ancient Jomon of Japan (Case Studies in Early Societies). Cambridge University Press, Cambridge.

Haslam, M.

2005. Starch Grain Taphonomy and the Interpretation of Archaeological Residue Analyses. In Australasian Archaeometry Conference 2005. Plant Microfossils and the Archaeological Record, edited by J. Field. Australian Key Centre for Microscopy and Microanalysis, The University of Sydney, NSW 2006, Australia. 
Kamijo, N.

2007. Jomon Jidai no Ishizara, Daiishi no Kenkyu: Keitai-bumpu wo Chusin ni [Stone Slabs in the Jomon Period: Morphological Types and Their Distribution]. Kobunka Danso 56:25-54.

Kodama, K.-i., and K. Nakamura

1995. Okunonita iseki - Oku-arashi iseki: Kaso Kikan-nodo Seibijigyo (Tachiyamachiku) ni Tomonau Maizo-bunkazai Hakkutsu Chosa Hokokusyo 1 [The Okunonita Site and Oku-arashi Site]. Nishino-omote-shi Maizo-bunkazai Hakkutsu Chosa Hokokusyo 7. Kagoshima Prefectural Archaeological Center, Aira-cho.

Loy, T., and H. Barton

2006. Post-Excavation Contamination and Measures for Prevention. In Ancient Starch Research, edited by R. Torrence and H. Barton, pp. 165-167. Left Coast Press, Inc., Walnut Creek.

Matsui, A., and M. Kanehara

2006. The Question of Prehistoric Plant Husbandry During the Jomon Period in Japan. World Archaeology 38(2):259-273. doi:10.1080/00438240600708295.

Mercader, J., T. Bennett, and M. Raja

2008. Middle Stone Age Starch Acquisition in the Niassa Rift, Mozambique. Quaternary Research 70:283-300. doi:10.1016/j.yqres.2008.04.010.

Miyawaki, A.

1977. Nihon no Shizen-shokusei zu [Vegetation zones in Japan]. In Nihon no Shokusei [Japanese Vegetation], edited by A. Miyawaki, pp. 535. Gakushukenkyusya, Tokyo.

Obata, $\mathrm{H}$.

2004. Reexamination of Botanical Foods Utilization and Polished Stone Tools of Initial and Early Jomon in Southern Kyushu. Kumamoto Journal of Culture and Humanities: Studies in History 82:17-45.

Okamura, M.

1997. Nihon-retto no Minami to Kita deno Jomon Bunka no Seiritsu [The Formation of Jomon Culture in the Southern and Northern Parts of Japanese Islands]. The Quarternary Research 36(5):319-328.

Pearson, R.

2006. Jomon Hot Spot: Increasing Sedentism in South-Western Japan in the Incipient Jomon (14,000-9250 cal. BC) and Earliest Jomon (92505300 cal. BC) Periods. World Archaeology 38(2):239-258. doi:10.1080/ 00438240600693976.

Piperno, D.R., and I. Holst

1998. The Presence of Starch Grains on Prehistoric Stone Tools from the Humid Neotropics: Indications of Early Tuber Use and Agriculture in Panama. Journal of Archaeological Science 25:765-776. doi:10.1006/ jasc.1997.0258. 
Suzuki, C.

1988. Preliminary Studies on the Food and Subsistence Economy of the Preceramic Age in Japan. Suzaku, Bulletin of the Museum of Kyoto 1:1-40.

Tahira, Y., and Y. Nohira

2003. Tachikiri iseki: Ken-ei Hata-chitai Nodo-mo Seibijigyo ni Tomonau Maizo-bunkazai Hakkutsu Chosa Gaiyo Hokokusyo [The Tachikiri Site]. Nakatane-cho Maizo-bunkazai Hakkutsu Chosa Hokokusyo 6. Nakatane-cho Kyoiku-iinkai, Nakatane-cho.

Takahashi, R., and L.A. Hosoya

2002. Nut Exploitation in Jomon Society. In Hunter-Gatherer Archaeobotany, edited by S.L.R. Mason and J.G. Hather, pp. 146-155. University College of London, London.

Tozaki, K., K. Aosaki, J. Tachigami, M. Yoshinaga, O. Ushinohama, S.-i. Nagano, and E. Miyata

1981. Kakuriyama • Kaminoki-yama iseki: Kyushu Jukan Jidosha-do-kankei Maizo-bunkazai Hakkutsu Chosa Hokokusyo V [The Kakuriyama Site and Kaminoki-yama Site]. Kagoshima-ken Maizo-bunkazai Chosa Hokokusyo 13. Kagoshima Kyoiku-iinkai, Kagoshima.

Tsukada, M.

1983. Vegetation and Climate During the Last Glacial Maximum in Japan. Quaternary Research 19:212-235. doi:10.1016/0033-5894(83)90006-6.

Watanabe, M.

1975. Jomon Jidai no Shokubutsu-shoku [Plant Food in the Jomon Period]. Selected Archaeological Textbook 13. Yu-zankaku, Tokyo.

Yasuda, Y.

1980. Kankyo Koukogaku Kotohajime: Nihon retto 2 mannen [Introduction to Environmental Archaeology]. Nihon Syuppan Kyokai, Tokyo. 